\title{
A Revolução Cubana nos documentários de Chris Marker
}

\section{The Cuban Revolution in Chris Marker's documentary films}

\section{Carolina Amaral de Aguiar}

A presença de Cuba nas discussões políticas entre artistas e intelectuais na França durante os anos 1960 e 1970 pode ser exemplificada por um episódio narrado por Jorge Semprún em Montand: la vie continue (1983). Nesse livro memorialístico, o escritor demonstra suas divergências com Régis Debray e descreve uma situação embaraçosa ocorrida em 1974 na casa de campo de Yves Montand e da atriz e escritora Simone Signoret, em Auteuil. Lá jantavam os dois antagonistas e outros convidados do casal (entre os quais Chris Marker). Semprún alega que durante muitos anos evitara falar sobre Cuba com Debray, que se havia tornado uma referência para a esquerda francesa após o sucesso do ensaio Révolution dans la révolution? (1967), obra foquista. Porém, foi justamente um livro

Carolina Amaral de Aguiar é mestre em Estética e História Social e doutoranda em História Social pela USP (bolsista FAPESP); é integrante do programa internacional USP-Cofecub "Exercícios de história cultural conectada: caminhos cruzados entre Brasil, América Latina e França” (amaral_carol@yahoo.com.br). Artigo recebido em 24 de dezembro de 2012 e aprovado para publicação em 9 de abril de 2013. 
que repensava a estratégia armada que desencadeou a briga em Auteuil. Debray indagou a opinião de Semprún sobre La critique des armes (1974), dando-lhe a oportunidade de dizer o quanto abominava a defesa assumida pelos intelectuais franceses dos métodos e da ditadura de Fidel Castro.

A breve descrição desse episódio, que parece ter tido um final muito mais constrangedor do que sugere o parágrafo acima, exemplifica como o modelo de socialismo cubano esteve na pauta das discussões francesas desde a vitória da Revolução (1959) - e a posterior declaração de seu caráter socialista (abril de 1961) - até os anos 1970. A presença de Chris Marker como um participante-observador "orgânico" desse grupo da intelectualidade também é um dado importante desse relato, já que, apesar da crítica feroz à Régis Debray, Semprún não cita os filmes realizados por Marker (a quem elogia) para defender as ações de Fidel Castro.

O episódio exemplifica também o papel central da Revolução Cubana nos debates intelectuais entre o final dos anos 1950 e meados da década de 1970. Claudia Gilman (2012) verifica essa centralidade na esquerda intelectual latino-americana, apontando sua reverberação na intelectualidade europeia. Considerado um fato original por ser uma revolução socialista vitoriosa sem a participação do Partido Comunista, o processo revolucionário cubano aparecia como uma alternativa ante ao abalo da confiança na União Soviética após a divulgação dos crimes do stalinismo, em 1956. Assim, Gilman identifica que a Revolução rompeu com uma perspectiva eurocêntrica, ocidentalista e do Atlântico Norte para dar lugar a uma perspectiva policêntrica.

A ideia de uma perspectiva policêntrica ajuda a compreender como a Revolução Cubana foi apropriada pelos meios artísticos e de teoria política da França, tornando-se um parâmetro para pensar a própria democracia desse país. Para contribuir nesse debate, propõe-se a análise de dois documentários de Marker: Cuba si ${ }^{1}$ (1961) e La bataille des dix millions (1970). Essas duas produções elaboraram um discurso sobre o processo revolucionário cubano e levaram a intercâmbios com o Instituto Cubano del Arte e Industria Cinematográficos (ICAIC), que foram fundamentais para o estabelecimento de práticas cinematográficas comuns entre Europa e América Latina.

Alfredo Guevara (2009), então dirigente do ICAIC, atribui o contato do governo revolucionário com o grupo de intelectuais de Paris ao interesse do ator Gérard Philipe e sua mulher, Anne Philipe, pela Revolução Cubana. Porém o casal mais emblemático dessa aproximação foi Jean-Paul Sartre e Simone de Beauvoir, que estavam entre os primeiros franceses a visitar a Cuba revolucionária, entre fevereiro e março de 1960. Em meio a outros compromissos, eles estiveram nas dependências do ICAIC e foram tema de um texto publicado na edição $\mathrm{n}^{\circ} 1$ da revista Cine Cubano, "Simone de Beauvoir y Sartre hablan de cine" (1960). 
Entre os cineastas estrangeiros não pertencentes ao bloco socialista, ${ }^{2}$ destaca-se a colaboração de Joris Ivens com o ICAIC, quando rodou Carnet de viaje e Pueblo armado (ambos de 1961). O holandês esteve em Cuba em setembro de 1960, sendo contratado para organizar uma escola para documentaristas, concretizada apenas de modo informal. Nesse período, percorreu a ilha acompanhado de cineastas do Instituto, cobrindo os enfrentamentos entre o Exército Rebelde e os contrarrevolucionários. Cabe ressaltar que entre as atribuições dos realizadores convidados pelo Estado cubano estava a de propagandear os feitos da Revolução na Europa, função desempenhada pelos filmes analisados neste artigo.

No livro Cinema cubano, Mariana Villaça (2010) destaca que durante os chamados "anos dourados" da cinematografia em Cuba, a década de 1960, inúmeros cineastas passaram pelo Instituto, que priorizou colaboradores que tivessem comprovada experiência no cinema documental, gênero eleito como o prioritário para o processo revolucionário. Foi o caso de Ivens e também de Chris Marker, que começou o projeto Cuba si em janeiro de 1961. Essa tendência levou ainda outros documentaristas ao país, como Mario Gallo, que rodou Arriba el campesino e Al compás de Cuba (ambos de 1960), e Agnès Varda.

O caso de Varda deve ser destacado, já que a cineasta e Chris Marker têm um longo histórico de amizade e colaboração, que remete pelo menos ao Groupe des Trente (1953). A realizadora participou também do projeto Loin du Vietnam (1967), a partir do qual se criou a produtora militante Service pour le Lancement des Euvres Nouvelles (SLON). Em Cuba, ela esteve a convite do ICAIC em 1962, quando rodou Salut les cubains! (1963), que teve como assistente a cubana Sara Gómez. O documentário de Varda apresenta semelhanças com o de Marker, como será abordado a seguir.

É necessário ressaltar, entre as presenças europeias na Cuba pós-revolucionária, a de Régis Debray. De acordo com Jacques Leenhardt e Pierre Kalfon (1992), ele se ofereceu frente à embaixada de Cuba em Paris para lutar nas forças internacionalistas durante a invasão norte-americana da Baía dos Porcos (junto com seu amigo Bernard Kouchner, que posteriormente se tornaria um dos fundadores do programa Médicos sem Fronteiras). Os autores afirmam (com bastante ironia) que, mesmo sem conhecer uma palavra de espanhol, Debray alfabetizou camponeses da Sierra Maestra. Anos depois, em 1965, voltou à ilha a convite do próprio Castro, transformando sua nova experiência em Révolution dans la révolution? (1967). Afinal, o autor havia deixado Cuba para acompanhar Ernesto Che Guevara na Bolívia e, como consequência, foi condenado a 30 anos de prisão (em um episódio de difíceis articulações diplomáticas que levou Debray ao centro dos noticiários internacionais). Marker refere-se a esse livro em alguns de seus filmes, como La spirale (1976) e O fundo do ar é vermelho (1977). 
A colaboração entre as esquerdas cubana e europeias (especialmente a francesa) envolveu ainda a circulação de técnicos como agrônomos e economistas. Esse panorama mostra que a troca entre Cuba e a Europa costumava ser de mão dupla (não mais sob uma perspectiva eurocêntrica), sendo que os europeus buscavam na ilha alternativas possíveis para sua própria militância, enquanto, para os cubanos, interessava difundir os ideais revolucionários, assim como capacitar tecnicamente as novas instituições de Estado que se formavam ou se renovavam. Nesse sentido, a contribuição no campo cinematográfico, em torno das atividades do ICAIC, é exemplar. O documentário Cuba si pode ser analisado como uma propaganda da Revolução para espectadores franceses, mas também como um laboratório de experimentação e trocas no dia a dia do set de filmagem.

\section{Cuba si (1961)}

Marker chegou a Cuba em dezembro de 1960 e logo iniciou gravações para Cuba si. A sequência inicial do filme mostra crianças pedindo seus presentes de Natal, que na ilha são ofertados no Dia de Reis. O documentário une a tradição festiva da data com as comemorações do segundo aniversário da Revolução, em $1^{\circ}$ de janeiro de 1961. Esses dois aspectos são bastante explorados na produção: a autenticidade cultural do povo cubano e a liberdade de exercê-la em sua plenitude após a libertação promovida pelos revolucionários. Marker exibe o nascimento de uma nova nação, representada pelos pedidos de meninos e meninas aos reis magos - alegoricamente barbudos como os guerrilheiros. A voz over anuncia:

Era o ano passado, em Havana. Preparávamo-nos para celebrar nesta ordem: o $1^{\circ}$ de janeiro, que é o $1^{\circ}$ de janeiro, o 2 de janeiro, que é o aniversário da Revolução, e o Dia de Reis, que é o Natal - o verdadeiro Natal, o dia dos presentes, quando ofertamos às crianças os bebês-cachorros, que crescerão, os bebês-coelhos, que crescerão, os periquitos batizados de peixes, os ursos e as bonecas, e também os bebês metralhadoras, que crescerão! (Cuba si, 1961) ${ }^{3}$

A militarização aparece como uma característica da sociedade cubana que é amplamente exaltada em Cuba si. O documentário é repleto de cortejos militares, sempre mesclados à multidão nas ruas, caracterizada como uma soma de pessoas multiétnicas. Soldados caminham com metralhadoras, mas também com tambores. A celebração é garantida, na visão de Marker, pela unidade do 
povo e sua disposição de se defender dos inimigos internos e externos. Esse país recém-liberto, "ex-quintal” dos Estados Unidos, está agora nacionalizado, porém não sem tensões e ameaças.

O clima de festa, mas também de conspiração, mostrado em Cuba si, condiz com os desafios enfrentados pelo Estado cubano no princípio de 1961 . Em carta ao embaixador de Cuba na França, Harold Gramatges, de janeiro de 1961, Alfredo Guevara (2009) anuncia a presença de Marker no país e sua intenção de rodar um documentário com o cubano Eduardo Manet, declarando estar ciente de que o diplomata fora o responsável pela vinda do cineasta francês. $\mathrm{Na}$ mesma correspondência, Guevara compartilha a preocupação com as constantes ameaças dos Estados Unidos, que haviam rompido relações diplomáticas e tinham planos de agressão.

De fato, os longos meses dedicados a Cuba si possibilitaram a incorporação de cenas do ataque norte-americano à Baía dos Porcos, em 17 de abril de 1961, nas sequências finais do documentário. De volta à França, Marker insere na montagem fotos de jornais franceses sobre o episódio e narrações de rádio. A voz over anuncia que os relatos da imprensa europeia o remeteram aos passeios feitos meses antes em Havana. Assim, ele caracteriza suas próprias lembranças como oráculos de uma situação que já se anunciava. São essas lembranças, por outro lado, que lhe permitem confiar na resistência do povo cubano, conforme expõe a voz over.

Os planos gravados em Cuba se convertem em souvenirs (como objetos trazidos de uma viagem) quando vistos em Paris. A questão do local de onde fala o realizador é fundamental em toda a obra de Marker, que, ao se remeter a lugares distantes, assume um ponto de vista estrangeiro. É possível perceber em suas produções que abordam processos latino-americanos, como Cuba si, um diálogo direto com a sociedade francesa, assim como a internacionalização do discurso político.

Após uma longa sequência na qual uma marcha militar se transforma em um grande desfile carnavalesco de conga, Marker declara que fora de Havana o resto do mundo segue seu curso normalmente. Nesse momento, vários planos curtos se sucedem: corrida de automóvel, desfile de moda, competição de beleza de animais, reuniões de chefes de Estado, astronautas, guerras e touradas. Esse pot-pourri de imagens é comentado pela voz over, que guia um percurso pelas diversas regiões do mundo: França, Argélia, América, Congo, Laos, África. O luxo e a violência disseminados, fenômenos associados nessa sequência, não estão presentes em Cuba.

A ilha é, em Cuba si, uma exceção. Um lugar onde a militarização é libertadora. Onde as armas e os tambores, o exército e o povo, compartilham as ruas em enormes manifestações de apoio ao governo. As metralhadoras cubanas, as 
mesmas desejadas pelas crianças patriotas no início do filme, são as armas de defesa, enquanto as utilizadas pelas potências imperialistas são as de ataque. Nesse sentido, vale destacar que há um julgamento ético da violência, pelo qual ela pode ser considerada "boa" ou "má" de acordo com o fim ao qual se destina. Há também uma clara alusão às ideias de Frantz Fanon (2011), assim como à defesa da violência como "parteira" da História, realizada por Sartre no prefácio de Les damnés de la terre.

Entre as estratégias narrativas usadas para transmitir o enfrentamento entre essas duas forças - luta armada libertadora e poderio militar imperialista (revolução e contrarrevolução) -, está o uso de imagens metafóricas. A tensão que antecede o ataque à Baía dos Porcos é posta em cena por crocodilos submersos em Playa Girón que se preparam para dar o bote, assim como os vizinhos yankees e os anticastristas cubanos. As tomadas desses traiçoeiros animais são acompanhadas pela transmissão de uma rádio francesa que questiona o apoio que a "ditadura de Fidel Castro" teria do povo cubano. Um corte introduz cenas da invasão norte-americana e do poderio militar defensivo de Cuba. A voz over declara que em 20 de abril de 1961 o mundo não apenas viu a vitória do governo revolucionário, como apreendeu que seu povo estava pronto a defendê-lo.

A sequência final de Cuba si deixa claro que se trata de um filme militante no sentido mais estrito do termo, feito para atuar em prol de uma causa - no caso, a Revolução Cubana. A produção exalta o processo em curso no país em tom celebrativo, e inicialmente receberia o nome de Celebración. Mesmo a exclamação denominativa em favor da ilha, "Cuba si", tirada de um dos lemas do governo revolucionário, reforça o caráter propagandístico do documentário. Sua intenção é evidentemente contradizer a visão negativa de Fidel Castro hegemônica na imprensa europeia, sobretudo francesa. Esse objetivo está claro, por exemplo, na exibição de manchetes críticas a Cuba retiradas dos periódicos europeus.

Cuba si acusa que, para o resto do mundo, é mais fácil ressuscitar o mito e associar Fidel Castro à figura de Robin Hood do que entender sua verdadeira origem. Uma sequência de justaposição de gravuras e trechos de um filme de ficção ${ }^{4}$ representando o "príncipe dos ladrões" é intercalada a imagens documentais da guerrilha na Sierra Maestra, ligando Castro e Robin Hood por meio da seleção de cenas que lembram o estereótipo do homem "bárbaro", um barbudo vivendo nas matas e comendo com as mãos. O comentário proferido pela voz over, no entanto, torna a situação mais complexa:

Trata-se, talvez, de Robin Hood... Somente tomar dos ricos e dar aos pobres, no século em que estamos, não consiste necessariamente em atacar as diligências. E quando Robin Hood leu Marx, 
quando nas suas montanhas ele prepara as leis e reformas da futura república, uma parte do mundo começa a se dar conta com pesar que está atrasada também, mais que um Robin Hood. Assim, morrem as lendas. O mito de Robin Hood se desfaz em pedaços. Em seu lugar, uma Revolução. (Cuba si, 1961)

Buscando ir além do mito, Marker insere planos de Castro estudando. A visão do guerrilheiro como um "bárbaro" se inverte, por meio de seu retrato como um intelectual. Nessa etapa, Cuba si se assume como um contraponto aos estereótipos negativos em torno do líder cubano, dedicando-se a entender inclusive suas contradições. Grandes manifestações em apoio à causa revolucionária "desmentiriam" nas estratégias de Marker a visão de que se tratava de um ditador. $\mathrm{O}$ documentário caminha para o argumento de que, ao invés de um fenômeno totalitário - como defendia a imprensa francesa -, a Revolução era um exemplo de democracia direta.

Para perceber esse fato, faltava que o estrangeiro compreendesse os aspectos culturais da Revolução Cubana. A voz over comenta que, enquanto as cenas de fuzilamento de um ex-comandante de Batista rodaram o mundo, as dos prisioneiros políticos disputando competições de xadrez com seus guardas permaneciam desconhecidas (até serem mostradas em Cuba si). Enquanto as manchetes da imprensa francesa publicavam que Castro era acusado de trair seus companheiros pelo Departamento de Estado, as faces dos engravatados "almofadinhas" que formavam esse órgão eram desconhecidas. Assim, o realizador francês se dedica a trazer contra-argumentos ao discurso da mídia francesa, gerando um panorama extremamente favorável a Cuba.

Marker lança a seguinte pergunta: quem é Fidel Castro? Filho de proprietário de terras, aluno jesuíta e fundador da primeira república socialista das Américas. Como se deu essa metamorfose? A resposta é inserida na montagem por meio de um fragmento de entrevista com o próprio chefe de Estado, registrada originalmente para a televisão francesa. Castro atribui sua postura a uma vocação política, a uma tendência natural à justiça e a um ambiente favorável à revolução - como o que estava dado em Cuba devido à desigualdade social. Ele se explica ao público francês:

Não pode haver revolução fora de tempo. Quantos Marats, e quantos Dantons e quantos Robespierres haverão nascido na França desde que a França existe. E, no entanto, somente um Marat, somente um Danton e somente um Robespierre se transformaram em re- 
volucionários. Quando? Quando a monarquia feudal já estava em decadência. (Cuba si, 1961)

Em outro trecho dessa mesma entrevista, Castro cita novamente a França para explicar por quê, após dois anos da Revolução, ainda não haviam ocorrido eleições. É evidente que a escolha dessa sequência por Marker visava a rebater a acusação de que se tratava de uma ditadura. Lembrando os anos durante os quais a ilha estivera submetida ao governo de Fulgencio Batista, o líder cubano considera a hipótese de instaurar um processo eleitoral posterior à institucionalização da Revolução. Ele compara o país latino-americano ao europeu, estranhando o fato de os franceses não entenderem que o "eleitorismo" não resolveria os problemas de uma nação. E completa: enquanto na França a população estava descontente, em Cuba haveria eleições todos os meses em praça pública, visíveis na aclamação popular. Claramente, esse trecho indica a posição de Marker ao lado das análises esquerdistas que consideravam a ilha um exemplo de democracia direta (como já havia defendido Sartre, por exemplo).

Essa ênfase em uma nova forma de democracia, que rebatia as críticas ao caráter ditatorial da Revolução Cubana, respondia ao diagnóstico de que a Europa vivia uma "idade de ferro" em oposição ao "fermento revolucionário" de outras regiões, conforme aponta Claudia Gilman (2012). A autora destaca que o terceiro-mundismo vinha ao encontro da urgência de um novo esquerdismo revolucionário, diante das fórmulas insuficientes em voga na esquerda europeia:

No mundo desenvolvido e próspero, quem havia transitado pelas hipóteses do marxismo contemplava perplexo sua própria realidade: a social democracia, o economicismo do proletariado que se mostrava não só incapaz, senão também pouco disposto a transformar radicalmente a sociedade. (Gilman, 2012: 47)

Essa oposição entre uma falsa social democracia, não representativa da vontade do povo, e o governo revolucionário aparece em Cuba si. Do ponto de vista da seleção de planos, são as cenas de multidão, sobretudo aquelas nas quais os cubanos civis aparecem mesclados às paradas militares (confirmando que, no caso de Cuba, as armas são libertadoras, e não opressoras), as que mais confirmam essa tese da democracia direta. Em relação às temáticas abordadas, o alinhamento militante do realizador com o Estado cubano valoriza aquelas que mostram as transformações do país. Sendo assim, além de celebrar, o documentário busca também propagandear essas mudanças. 
A música cubana está presente como um recurso sonoro de exaltação da Revolução. São muitas as cenas em que ela acompanha a multidão e as marchas militares. A principal delas é a sequência em que um cortejo militar se transforma inesperadamente em uma conga, dançada pelo povo que acompanhava a fanfarra. Outra canção fundamental é Después de un año, de Carlos Puebla, que celebra o primeiro aniversário do governo. O refrão "Y el pueblo después de un año repite, Gracias Fidel” exalta o apoio popular ao líder revolucionário e é usada pelo realizador com essa finalidade.

Além do clima festivo, a defesa de Cuba de Marker passa pela oposição entre o novo governo e o período em que Batista governou - essa sim, uma verdadeira ditadura. Ao final da primeira parte do documentário - que é dividido em dois blocos -, são alternadas tomadas gravadas durante o período de Batista com outras realizadas após a mudança de poder. Se antes havia palácios e pobreza extrema, se o povo era massacrado pela repressão militar - bem como os guerrilheiros que o defendiam -, em janeiro de 1959 do luxo palaciano sobrava apenas uma estátua de um "bebê Napoleão"5 (mais uma referência à história de seu próprio país que Marker insere).

A representação cênica de um mundo decadente e de outro emergente está em várias passagens do filme. Esse procedimento é evidente quando o realizador insere imagens do arquivo do ICAIC rodadas na Sierra Maestra. Concomitantemente aos registros de Ernesto Che Guevara, Raul e Fidel Castro e Camilo Cienfuegos, a voz over indica que o objetivo da guerrilha era destruir uma ditadura e construir uma sociedade nova. As cenas de vida compartilhada entre os guerrilheiros na mata anunciam aspectos de uma coletividade que iria, na visão do realizador, estar presente após a vitória. Além de armas, eles manuseiam a massa do pão, tijolos, máquinas de escrever e aparelhos eletrônicos.

Embora estejam presentes com mais frequência na segunda produção de Marker sobre Cuba, La bataille des dix millions, em Cuba si há algumas sequências em que o trabalho manual aparece como um valor desejável para essa nova sociedade. Se essa atribuição é evidente nas cenas da Sierra Maestra, ela volta na segunda parte do documentário, quando os ministros de Castro cortam cana-de-açúcar, dando o exemplo para a produção. ${ }^{6}$ Essa sequência é importante, pois se contrapõe à riqueza do império dos usineiros de Batista, época de exploradores e explorados. Na Revolução, essa distinção estaria ausente e todos trabalhariam em conjunto para o bem comum, como ocorrera nas matas entre os revolucionários.

A ideia é de uma passagem entre dois mundos, entre a Cuba antiga e a nova, entre Cuba e o resto do mundo, entre Cuba e a França. Na sequência em que a voz over descreve que a rádio francesa anunciara o ataque norte-americano em 17 de abril, um carro atravessa um túnel em Havana enquanto são proferidos 
comentários sobre as transformações revolucionárias. A expropriação de empresas pelo Estado, diz a voz over, é também a passagem de um mundo para outro. Nesse trecho, o caminho pelo túnel é um recurso que materializa cenicamente esse trânsito entre universos opostos.

Em Cuba si, aparecem alguns recursos estilísticos amplamente presentes na filmografia de Chris Marker. Um deles, sem dúvida, é o comentário marcante. Em suas produções, pode-se dizer que texto e imagem estão interligados, sendo que muitas vezes um questiona ou afirma com veemência o outro. A vozover tem o papel fundamental de trazer texto às imagens. Vale ressaltar que Marker começou sua carreira como ensaísta, atribuindo à palavra um peso tão grande quanto ao universo visual. Nesse documentário, a voz over apresenta algumas particularidades comuns a outras produções, como a ironia, o lirismo, o papel informativo e a função questionadora.

Para os cineastas do ICAIC, a estada de Chris Marker teve outra função além de divulgar na Europa os feitos da Revolução. No artigo "Tres semanas de trabajo junto a Chris Marker", escrito por Eduardo Manet para a Cine Cubano, está um relato sobre os métodos markerianos, visando a contribuir para a formação de documentaristas latino-americanos. Ele divide sua metodologia em duas categorias: geral (tomar o fato no instante em que é produzido, eleger fatos representativos e integrar figuras humanas à paisagem sempre que possível) e específica (registrar rostos em movimento, utilizar animais como metáforas e captar uma tendência da "alma nacional"). De maneira didática, Manet determina preceitos que podem ser seguidos, especialmente o de unir um cinema testemunhal e documental com a arte.

Um documentário necessita de métodos definidos, sensibilidade artística e engajamento político. São esses três aspectos que Manet "aprende" durante a estada de Marker. O artigo é interessante por narrar a vontade do realizador francês de registrar as mais diversas imagens, que poderiam eventualmente ser aproveitadas na montagem. Ele descreve, por exemplo, que as tomadas da comemoração do segundo aniversário da Revolução, que estão na sequência inicial de Cuba si, foram gravadas sem "medir a luz", com a "rapidez de uma metralhadora", focando em rostos, mãos e expressões.

Identificar as estratégias narrativas de Marker na obra dos cineastas do ICAIC é uma tarefa difícil, pois há métodos distintos presentes nesse grande conjunto de filmes e de realizadores cubanos. Porém algumas características que se tornaram hegemônicas nos documentários estão, de alguma forma, em Cuba si. Na descrição de Eduardo Manet está, por exemplo, a preferência pela rapidez do registro em detrimento da qualidade técnica da imagem. Esse procedimento de gravação condiz com alguns dos preceitos defendidos pelo cinema-verdade, ${ }^{7}$ para o qual a experiência vivida é o mais relevante na tomada fílmica. 
Mariana Villaça (2010) defende que o melhor termo para descrever esse tipo de cinema em Cuba é cineurgente, já que a ideia de tomadas oportunas que fossem ao encontro da realidade estava presente, mas nem todas as técnicas do gênero tal como realizado na Europa eram seguidas. Esse termo, cunhado por Santiago Álvarez, descrevia a necessidade de um registro rápido aliado a uma narração ágil, método que empregava nos Noticiero ICAIC Latinoamericano. Em Cuba si, essa parece ter sido a estratégia utilizada para gravar as manifestações de rua, a partir das quais Marker demonstra um sentimento de ver a História acontecer, ou seja, uma certa urgência em registrar e divulgar os momentos que vivenciava.

Vale destacar que se Cuba si se aproxima dos métodos usados por grande parte dos documentaristas do ICAIC (especialmente Álvarez) em suas técnicas de registro das imagens, ele difere substancialmente desse corpus fílmico na utilização do texto, bem como na montagem. Para Álvarez, por exemplo, há uma preferência por utilizar palavras em forma de entretítulos e uma importância pequena da voz over.

Em Marker, ocorre justamente o contrário. A voz over corrobora ou contradiz as imagens; estabelece uma ligação entre os diversos planos por meio de um texto autoral. Quando assume a posição espacial do realizador no momento da montagem, um francês de volta à terra natal relembrando sua estada, ela revela uma subjetividade que concede às imagens anteriores o papel de fragmentos de memória. Essa subjetividade assumida é um recurso pouco presente no cinema político cubano, com algumas exceções - Sara Gómez, Nicolás Guillén Landrián e Tomás Gutiérrez Alea (Paranaguá: 2003).

Nesse sentido, apesar das semelhanças entre o documentário de Marker e o de cubanos - o que comprovaria uma certa "escola" europeia -, são muitas as diferenças que permitem afirmar que o ICAIC desenvolveu um caminho autônomo, com a criação de estratégias narrativas próprias e o diálogo com outros atores (como os latino-americanos no contexto do Nuevo Cine Latinoamericano). Dessa maneira, há, por exemplo, mais proximidade entre produções como Cuba si e Salut les cubains!, de Agnès Varda, do que entre Cuba si e os filmes de Álvarez.

Apesar de algumas diferenças estilísticas e temáticas (o papel da mulher, por exemplo, é uma questão para Varda, bem como a religião afro), a cultura cubana, a mestiçagem e as mudanças positivas geradas pelo novo governo são aspectos celebrados em Salut les cubains! que já estavam em Cuba si. Se no documentário de Marker a canção exercia um papel importante, no de Varda ela é o elemento fundamental, desempenhando um papel narrativo e exemplificando a riqueza cultural do povo. Outro aspecto em comum é a exaltação das cenas de multidão e sua afirmação como "verdadeiros" momentos democráticos, corroborando a tese de que haveria nesse país uma nova forma de democracia direta. 
Essa breve comparação entre os dois documentários permite afirmar que Cuba si se tornou uma referência nos meios franceses para pensar a Revolução Cubana. Vale ressaltar que o filme foi censurado em 1961, época de sua produção, por defender o governo de Fidel Castro, tornando-se público apenas em setembro de 1963. Nessa ocasião, apareceram muitos textos na imprensa de esquerda exaltando-o, entre eles um artigo de Georges Sadoul (1963).

Em alguns desses artigos está presente a ideia de que Cuba si só foi liberado pela censura quando a vitória dos revolucionários passou a ser mais um fato histórico do que um acontecimento político recente, ou seja, quando o filme já perdera parte de seu poder de persuasão. Apesar de muito saudado pela esquerda e ainda uma referência de engajamento, em 1963 a "coqueluche" Cuba deixava de ser uma epidemia na França. Leenhardt e Kalfon apontam alguns episódios que contribuíram para o enfraquecimento dessa visão lírica e romântica: a crise dos mísseis (em outubro de 1962) e o acordo de venda de açúcar para o bloco socialista em 1963. Esses acontecimentos evidenciaram a dependência que o país latino-americano tinha da União Soviética, abalando a visão idílica frequente da gauche française. Nesse contexto, a tese da democracia direta, presente nos documentários de Marker e de Varda, perdia seu poder de persuasão.

Após a partida de Che Guevara para seguir a guerrilha em outras partes do mundo, em 1965, e sua morte na Bolívia, em 1967, abordar a Revolução Cubana passou a ser uma questão ainda mais delicada, como é possível perceber em outro documentário de Marker sobre a ilha: La bataille de dix millions (1970). Nessa produção, a celebração presente em Cuba si dá lugar a uma reflexão mais complexa sobre o tema, embora sem abrir mão da militância em favor do governo de Castro. Porém os argumentos presentes nessa militância serão outros.

\section{La bataille des dix millions (1970)}

Após a experiência de $C u b a$ si, Chris Marker se manteve à distância como um colaborador do ICAIC. Em 18 de agosto de 1968, por exemplo, enviou a Alfredo Guevara um roteiro do cineasta Peter Kassovitz. Marker propunha que o instituto cubano aceitasse a coprodução desse projeto. Manifestava ainda a vontade de exibir o recém-concluído Loin du Vietnam (1967) em Cuba. Esses casos mostram que a colaboração entre o realizador francês e o ICAIC não visava somente a novos modelos estéticos para o cinema militante, mas tinha objetivos concomitantes à produção e à difusão de filmes. A criação da SLON em 1967 foi fruto da busca de caminhos para realizar projetos sem depender das grandes produtoras. Nesse sentido, Marker procurava parcerias com instituições que pudessem fortalecer o coletivo. 
Um dos frutos da cooperação entre a SLON e o ICAIC foi La bataille des dix millions (1970). Produzido em um momento desfavorável a Cuba, nesse filme a celebração da Revolução de Cuba si dá lugar a uma minuciosa análise, que se reivindica como autocrítica. O lirismo da produção anterior é substituído pelo uso de longas sequências - muitas delas discursos de Fidel Castro com poucos cortes - que trazem explicações de ordem econômica para a crise na produção de cana-de-açúcar.

La bataille des dix millions foi montado com imagens do Noticiero e da produção Despegue a las 18.00 (1969), de Santiago Alvarez. ${ }^{8}$ Nesse período, Marker pôde acompanhar de perto o desafio assumido por Castro como solução para os problemas econômicos da ilha: produzir uma safra de 10 milhões de toneladas de açúcar. A voz over explica que esse era o único recurso renovável exportável em larga escala e que os 10 milhões representavam o potencial de venda para os países socialistas. Ela informa que União Soviética havia exigido uma planificação para 1970, e por isso a meta havia sido firmada para aquele ano. Mas afirma que Castro admitia, em seu programa, a existência de uma grande distância entre os números reais e os ideais. Esse primeiro trecho, composto pelas imagens do líder e por essa locução em over, compõe uma espécie de prólogo anterior aos créditos. Nele se conhece o plano, e também sua incapacidade de realização.

Assim, a derrota está anunciada desde o início. É necessário entendê-la. As cenas seguintes são extraídas do documentário Despegue a las 18.00, que retrata os esforços dos trabalhadores da parte oriental para produzir o açúcar. Se havia na montagem do realizador cubano o objetivo de verificar as falhas e incentivar o trabalhador, no documentário de Marker as mesmas imagens são usadas para sensibilizar o espectador para quem são esses "perdedores". Homens simples, mulheres e crianças. Enquanto a câmera foca o rosto de alguns deles, a voz over se defende de possíveis queixas vindas da esquerda que seu filme poderia receber:

Então, se nós mostrarmos essas imagens cotidianas de Cuba, essas filas intermináveis, essas dificuldades de provisão, esses "No hay", "não há", que eles repetem como um refrão, se nós dissermos que em Cuba há irritação, estaremos dando armas ao adversário? Um início de resposta talvez seja: essas imagens são de um filme cubano, Despegue a las 18:00, de Santiago Álvarez, e essas palavras foram pronunciadas - entenda você mesmo - por Fidel Castro. (La bataille des dix millions, 1970)

Fidel Castro é o grande protagonista do filme. Seu maior mérito destacado é a capacidade de fazer uma autocrítica. Ele está presente em vários e longos 
planos-sequências (dispositivo pouco habitual na filmografia de Marker). Na parte final, a voz over finalmente quantifica a derrota: ao invés dos 10 milhões de toneladas, foram produzidos 8,5 milhões, um recorde, mas distante do desejado. Além disso, os demais setores produtivos da ilha haviam ficado paralisados, agravando a crise econômica. Diante da catástrofe, Castro fala para uma multidão no dia 26 de julho de 1970, em um discurso que está nas cenas finais de $L a b a$ taille des dix millions. Antes das explicações técnicas, o líder faz um mea-culpa: "Como vocês veem, nós não temos medo de admitir quando nossos inimigos têm razão, nós vamos começar assinalando, em primeiro lugar, nossa responsabilidade a todos - a minha, em particular." (La bataille des dix millions, 1970).

Marker claramente se dirige aos setores da esquerda que não suportavam as críticas. Nesse sentido, pode-se dizer que La bataille des dix millions integra uma fase do realizador que repensa as próprias estratégias do cinema militante, sem abrir mão da defesa do socialismo. Procedimento semelhante está em $O n$ vous parle de Prague: le deuxième procès d'Arthur London (1971), documentário que registra os bastidores de $A$ confissão (L'aveu, 1970), de Costa-Gavras, baseado no livro de Arthur London, que combatia o stalinismo e relatava a perseguição sofrida por ele no ano de 1951, em Praga. Em On vous parle de Prague aparecem as questões: "O que é ser um verdadeiro comunista? E preciso fazer a autocrítica mesmo dando água ao moinho adversário?”.

Dessa maneira, La bataille des dix millions, produzido no mesmo período de On vous parle de Prague, analisa as razões da derrota não para "dar água ao moinho adversário", mas para evitá-la no futuro. É esse objetivo que faz do filme um balanço político e econômico, uma análise realista além dos idealismos. Marker insere um discurso de Castro no centenário de Lenin (abril de 1970), no qual ele afirma que, independentemente das diferenças, o apoio do Estado soviético era um privilégio para qualquer movimento revolucionário. A voz over confirma essa fala ao constatar que, se os Estados Unidos eram a grande ameaça à Revolução, era evidente que seu principal aliado seria o governo de Moscou. A questão cubana não é vista apenas como um episódio local, ela está ligada a interesses e lutas políticas em escala mundial. Nesse sentido, ela é, para o diretor, um interesse de todos.

Porém, além desse cenário internacional, estão homens e mulheres cubanos. Após o discurso de Castro, a montagem traz planos curtos de pessoas respondendo à mesma pergunta: o que você falaria para Lenin se ele estivesse vivo? "Quem?", “O fundador do socialismo, o russo?” são algumas das respostas. Essa simulação impossível é proposta a um pescador, a agricultores, à bailarina. A simplicidade das frases, incompletas ou pouco articuladas, evidencia uma distância entre as discussões teóricas e os problemas reais. A voz over une a análise política ao cotidiano do povo para justificar a crise da produção, vista como fruto do subdesenvolvimento: 
É com muitos desses homens que se trava essa batalha dos Dez Milhões. No início dessa empreitada, ninguém sabia ao certo se Fidel pensou que ela poderia ser perdida. Se bem que ganhar ou perder, diante do subdesenvolvimento, toda batalha já é uma vitória. (La bataille des dix millions, 1970)

Após essa fala, o documentário traz cenas da propaganda e do discurso de Castro na inauguração do programa (em 14 de julho de 1969), dirigindo-se a 30 mil machateros. Por um plano panorâmico em plongée é possível ver um campo de cana-de-açúcar onde trabalham milhares de pessoas. A montagem estabelece, nessa sequência, uma clara relação de causa e consequência entre as medidas oficiais do Estado e a resposta dos cubanos. Portanto, os motivos que explicam a derrota não passam pela falta de mobilização social. Ao contrário, mais uma vez, o governo revolucionário e o povo estão colados na visão do realizador.

Os argumentos que Marker cita para justificar a derrota passam por fatores de ordem econômica. O problema, anuncia a voz over, não está na colheita, mas em outras etapas necessárias para se chegar ao açúcar: o rendimento da cana, a qualidade técnica da queima, a distribuição de recursos para as usinas, o transporte da matéria-prima etc. No documentário, essas são as principais razões técnicas que explicam o fracasso dos 10 milhões. Trata-se de motivos que evidenciam as dificuldades de produzir em um país subdesenvolvido, com recursos limitados e pouco investimento em tecnologia e infraestrutura.

A questão do Terceiro Mundo não era o foco de Cuba si, ${ }^{9}$ cujos esforços exaltavam a cultura cubana, e não sua condição de nação subdesenvolvida. Em La bataille des dix millions eles são fundamentais para explicar as dificuldades enfrentadas pelo governo castrista. Outro elemento novo em comparação ao documentário anterior é a exaltação de uma solidariedade terceiro-mundista. $\mathrm{O}$ filme mostra filas de pessoas querendo doar sangue para vítimas de um terremoto no Peru. A voz over destaca uma fraternidade latino-americana e informa que o governo peruano se opôs ao imperialismo norte-americano. Na visão do realizador, os Estados Unidos são um inimigo comum, pois bloqueia o progresso real da América Latina.

Junto ao subdesenvolvimento, o boicote norte-americano a Cuba é um dos fatores para que a safra não seja alcançada. $O$ filme recorre a uma animação onde um personagem desembarca de um submarino e, quando tira seu disfarce, revela ser o Super-Homem. Essa vinheta introduz o episódio no qual a organização anticastrista Alpha-66 apreendeu equipamentos de dois barcos de pesca de uma cooperativa estatal cubana e deteve 11 pescadores em uma ilha das Bahamas. O evento causou protestos na frente da embaixada norte-americana em Havana, porém o fato teria sido difundido pela Reuters como uma manifestação em 
razão dos problemas relativos à safra de cana-de-açúcar. Como resposta, o governo cubano colaborou para que 100 mil manifestantes tomassem as ruas exigindo a libertação dos detidos.

Em La bataille des dix millions é correto afirmar que o subdesenvolvimento e o imperialismo são apontados como os dois fatores fundamentais para explicar a derrota. Embora proponha um discurso autocrítico, na análise dos acontecimentos Marker atribui a elementos externos às ações da esquerda as razões da derrota. Nas estratégias narrativas são usados inúmeros recursos para atrelar a imagem de Castro à do povo. Isso está claro na multidão que acompanha os discursos do líder, e mais ainda nas sequências dos trabalhadores nas lavouras.

Pode-se dizer que, mesmo repensando os possíveis erros da Cuba festiva da Revolução, La bataille des dix millions não rompe com um dos principais argumentos pró-Castro presentes em Cuba si: a ideia da democracia direta. Além das cenas da multidão apoiando o líder, recurso imagético explorado nos dois documentários, no filme de 1970 essa discussão é aprofundada nas sequências finais, que avaliam um provável legado da experiência dos 10 milhões: o desenvolvimento de núcleos autogestores, particularmente nas fábricas cubanas.

A retórica autocrítica de Fidel Castro é intercalada com entrevistas de trabalhadores. Eles respondem à questão: "O que mais te tocou no discurso de Fidel?" Uma das respostas é emblemática: "É o que ele diz sobre a participação dos operários nas decisões". Com os esforços concentrados nas lavouras de cana, as fábricas estiveram entregues aos seus próprios funcionários. Isso ocorreu principalmente em Santiago de Cuba, onde os operários demonstraram sua preocupação com a produção com "amor e entusiasmo incríveis" e revelaram-se como a classe potencialmente "mais revolucionária" (nas palavras do chefe de Estado). Portanto, uma das consequências positivas da derrota, aquela válida para a elaboração de novas estratégias, foi o surgimento de formas organizativas na indústria e a emergência de um novo sujeito revolucionário: o proletariado.

Após os créditos iniciais de La bataille des dix millions, Chris Marker problematiza como é pensar Cuba em 1970. Se, na época de Cuba si, a esquerda europeia festejava a chegada de Fidel Castro ao poder, ao longo dos anos 1960 diversos setores dessa esquerda romperam com esse paradigma, questionando a ausência de um processo eleitoral. Para muitos intelectuais e artistas era incompatível com as estratégias dos partidos esquerdistas europeus defender uma ditadura. Marker, porém, não havia rompido com sua visão positiva do país latino-americano e de seu líder, questionando o porquê de se abandonar os modelos quando eles demonstravam estar em crise. No início do documentário, a vozover coloca de maneira ácida: 
Este ano, Cuba não está exatamente na moda. Nós, europeus, nós amamos muito os povos em luta, desde que eles sejam completamente mártires ou completamente vitoriosos. Quando eles não se prestam mais a manifestos inflamados ou a um teatro militante, quando sua luta está no campo sem prestígio da realidade cotidiana, das dificuldades cotidianas, com tudo aquilo que ela tem de desagradável, nós nos afastamos deles e, como essas velhas atrizes que casam com homens cada vez mais jovens, nos casamos com causas cada vez mais jovens e procuramos, em algum outro lugar, um novo rosto para sonharmos. (La bataille des dix millions: 1970)

Comparando os dois filmes, pode-se dizer que Cuba si procurou rebater as críticas à Revolução Cubana feitas pela imprensa europeia e outros setores contrários a ela e a Fidel Castro. La bataille des dix millions reafirma a defesa do governo cubano, mas sugere analisar a derrota do episódio dos "10 milhões" como parte de uma luta mais ampla, contra o imperialismo e contra o subdesenvolvimento. Internamente, o filme dialoga mais com a própria esquerda europeia (ao contrário do que ocorria na produção de 1961, que rebatia críticas "direitistas"), especialmente os que encaravam Cuba como um modelo ultrapassado e os "stalinistas" que não permitiam abordar situações de derrota.

A partir da comparação entre os dois filmes, pode-se afirmar que surge no decorrer da década de 1960 a necessidade de revisões políticas internas (autocríticas), procedimento presente em várias produções de Marker. Essa postura levou-o a escrever uma carta a Alfredo Guevara em maio de 1971 se posicionando sobre o "Caso Padilla", quando o escritor Heberto Padilla foi acusado de "atividades subversivas" e preso (Guevara, 2009). Solto 38 dias depois, Padilla se apresentou junto à União de Escritores e Artistas de Cuba (UNEAC) para se desculpar publicamente e assinou uma "confissão" em nome de outros escritores também. Marker se dirigiu a Guevara de maneira afetuosa, mas caracterizou a autocrítica do escritor cubano como "grotesca" e "inverossímil" e comparou o fato com os processos de Moscou. Elogiou também a postura do escritor Norberto Fuentes de não "confessar" sob pressão do governo de Cuba.

Para Claudia Gilman (2012), o "Caso Padilla" foi um dos aspectos que colaboraram para o enfraquecimento do papel central da Revolução Cubana nos debates intelectuais. O episódio representou uma fratura, colocando em discussão temas como a liberdade de criação e o lugar dos escritores no processo revolucionário. Dessa forma, embora não tenha rompido definitivamente com a Revolução Cubana, Marker acompanhou o movimento de muitos artistas e intelectuais que se afastaram do projeto revolucionário após esse episódio, como já haviam feito Sartre e Simone de Beauvoir. 
1. Optou-se por utilizar a grafia "Cuba si", tal como aparece nos entretítulos da produção de Marker, em detrimento de "iCuba sí!", como seria o correto em espanhol.

2. Entre os pioneiros do bloco socialista a visitar o ICAIC, Mariana Villaça (2010) ressalta a presença de Kurt Maetzig, Vladimir Cech e Roman Karmen.

3. Os trechos transcritos dos filmes analisados foram traduzidos do francês para o português pela autora, assim como as demais citações bibliográficas cujos originais se encontram em francês ou em espanhol. É necessário destacar que o texto da voz over de Cuba si está publicado integralmente em Commentaires 1 (Marker, 1967).

4. As cenas de ficção usadas nessa sequência foram retiradas do filme Robin Hood (1922), de Allan Dwan.

5. Vale destacar que, se a primeira metade do filme começa com imagens dos "novos bebês" adquiridos pelas crianças no Dia de Reis, como os "bebês metralhadoras", esse "bebê Napoleão" decadente, abandonado em um jardim de um palácio em ruínas, simboliza a troca de uma sociedade por outra. A passagem de um bebê a outro representa o fim de uma situação colonial e a emergência da emancipação política.

6. Essa valorização do trabalho manual e a representação dos revolucionários como trabalhadores se relacionam à ideia de um "homem novo", tal como entendida por Ernesto Che Guevara. Pericás (1998) ressalta que, embora esse conceito fosse anterior, ele foi atrelado ao plano de desenvolvimento econômico instaurado após a Revolução Cubana, convertendo-se em um sistema de incentivos que entendia o máximo aproveitamento da mão de obra como meio de construir o socialismo. Esse sistema foi aplicado inicialmente na produção de cana-de-açúcar e, posteriormente, estendeu-se à agricultura em geral eà indústria. Vale destacar que o filme $L a$ bataille des dix millions é uma representação máxima dessa política, assim como de sua derrocada. Em Cuba si aparece a filosofia de um "homem novo" surgido em uma nova sociedade socialista, confirmando a tese de que esse conceito presente nas reflexões de Guevara ecoou em outros imaginários extra-Cuba: "De qualquer maneira, as ideias do revolucionário argentino tiveram de fato uma influência grande, não só nas concepções gerais do governo da ilha como também no imaginário dos movimentos de esquerda em toda a América Latina, assim como apresentaram consequências reais na economia e política de Cuba na época em que ele era um dos principais dirigentes daquele país" (Pericás, 1998: 107).

7. É necessário enfatizar que Marker é considerado um dos pioneiros do cinema-verdade surgido na França no início dos anos 1960. No entanto, na maior parte de suas obras, várias práticas usuais desse cinema não estão presentes, como o uso do som direto.

8. Nessa mesma época, Marker produziu dois documentários sobre o Brasil montados com material recebido de Cuba: $O n$ vous parle du Brésil: tortures (1969) e On vous parle du Brésil: Carlos Marighela (1970).

9. Cabe ressaltar que o debate sobre a questão do subdesenvolvimento ganhou força ao longo dos anos 1960, especialmente em Cuba. Em 1966, o país sediou a Primera Conferencia Tricontinental de La Havana, que fundou a Organización de Solidaridad de los Pueblos de África, Asia y América Latina (OSPAAAL). No ano seguinte, foi realizada, também em solo cubano, a conferência da Organización Latinoamericana de Solidaridad (OLAS). 
Referências bibliográficas

DEBRAY, Régis. Revolução na revolução?. São Paulo: Parma, s/d.

DREYER, Sylvain. Rhétorique de l'engagement critique. Regards de cinéastes et d'écrivains français sur la révolution cubaine (années 1960 et 1970). Revue de Sciences humaines, n. 11, 2006. Disponível em: $<$ http://traces.revues.org/246>. Acesso em: 22 dez. 2012.

GILMAN, Claudia. Entre la pluma y el fusil. Buenos Aires: Siglo Veintiuno, 2012.

GUEVARA, Alfredo. ¿Y sifuera una huella?. Madri: Nuevo Cine Latinoamericano, 2009.

FANON, Frantz. Euvres. Paris : La Découverte, 2011.

LEENHARDT, Jacques; KALFON, Pierre. Les Amériques Latines en France. Paris: Gallimard, 1992.

MANET, Eduardo. Tres semanas de trabajo junto a Chris Marker. Cine Cubano, Havana, v. 4, dez./jan. 1961, p. 24-33.
MARKER, Chris. Commentaires 1. Paris: Les Éditions du Seuil, 1967.

La bataille des dix millions. Feune Cinéma, Paris, n. 50, nov. 1970, p. 39-48.

PARANAGUÁ, Paulo Antonio (ed.). Cine documental en América Latina. Madri: Catédra, 2003.

PERICÁS, Luiz Bernardo. Che Guevara e o homem novo. In: COGGIOLA, Osvaldo (org.). Revolução cubana: história e problemas atuais. São Paulo: Xamã, 1998.

SEMPRUM, Jorge. Montand, la vie continue. Paris: Denoël; Clims, 1983.

SIMONE de Beauvoir y Sartre hablan de cine. Cine Cubano, Havana, v. 1, 1960, p. 25.

VILLAÇA, Mariana. Cinema cubano: Revolução e política cultural. São Paulo: Alameda, 2010.

\section{Resumo}

Nos anos 1960 a Revolução Cubana ocupou o centro do debate entre os intelectuais de esquerda na França. Por outro lado, o governo revolucionário convidou europeus para colaborar com o desenvolvimento de novas instituições, caso do ICAIC. Chris Marker, um dos convidados desse instituto, estabeleceu trocas com realizadores cubanos e montou dois documentários analisados neste artigo: Cuba si (1961) e La bataille des dix millions (1970). O primeiro visava a combater as críticas da imprensa conservadora a Fidel, enquanto o segundo se voltou para a própria esquerda que abandonava Cuba como um modelo.

Palavras-chave: Revolução Cubana; Chris Marker; documentário; circulação de idéias; democracia direta. 


\begin{abstract}
During the 1960's the Cuban Revolution was in the center of the French intellectual debates. On the other hand, the revolutionary government invited Europeans to collaborate with the development of new institutions as the ICAIC. Chris Marker, invited by the institute, established exchanges with Cuban film-makers and made the two documentary films that are analyzed in this article: Cuba si (1961) and La bataille des dix millions (1970). If the first one refutes the critiques addressed to Fidel by the conservative press, the second one turns itself to the left which was abandoning the Cuban model.

Key words: Cuban Revolution; Chris Marker; documentary film; circulation of ideas; direct democracy.

\section{Résumé}

Aux années 1960 la Révolution Cubaine a occupé le centre du débat des intellectuels de gauche en France. D'autre part, le gouvernement révolutionnaire a invité des Européens à collaborer pour le développement de nouvelles institutions comme l'ICAIC. Chris Marker, invité par cet Institut, a établi des échanges avec des réalisateurs cubains et a fait les deux documentaires analysés dans cet article: Cuba si (1961) et La bataille des dix millions (1970). Le premier répondait aux critiques de la presse conservatrice à Fidel, alors que le deuxième réfléchissait sur la gauche elle-même et son progressif détachement du modèle cubain.

Mot-clés: Révolution Cubaine; Chris Marker; documentaire; circulation d'idées; démocratie directe.
\end{abstract}

